\title{
THE EFFECTS OF EATING AND OF SHAM FEEDING UPON THE ABSORPTION OF VITAMIN A PALMITATE IN MAN ${ }^{1}$
}

\author{
BY ALBERT I. MENDELOFF \\ (From the Nutrition Research Laboratory, Department of Preventive Medicine, Washington \\ University School of Medicine, and The Barnes Hospital, St. Louis, Mo.)
}

(Submitted for publication January 11, 1954; accepted March 23, 1954)

It is the usual practice to test the intestinal absorption of specific nutrients in man by first feeding a test dose of the pure nutrient to the fasting subject, and then determining in samples of blood or urine taken over various subsequent periods of time the amount of the nutrient present in the blood or excreted in the urine. In the case of vitamin A absorption, such tests have been performed either to study its assimilation as a vitamin, or as an indicator substance correlated more or less closely with the general absorption of fats. That vitamin $A$ in oily solution is absorbed by man in a manner closely associated with the absorption of the oil in which it is dissolved, most studies would agree (1-3). When vitamin A acetate or palmitate or natural esters are given, dissolved in oil, the normal human subject exhibits an increase in the total vitamin A concentration of his blood serum for the succeeding 3 to 8 hours. The rate at which the serum levels rise, and the maximum concentrations attained are widely variable; consequently, many arbitrary standards for "normal" vitamin A tolerance tests have been set. It is generally agreed that the normal human subject should show a rise in the serum vitamin A concentration to at least four times the fasting level, or to a level greater than 100 micrograms per $100 \mathrm{ml}$. serum, during the 4 to 6 hours following ingestion of a test dose of 75,000 to 150,000 micrograms of an esterified form of vitamin A in oily solution (2-4).

In the course of some studies with vitamin $\mathrm{A}$ tolerance tests, using as a test dose 100,000 micrograms of synthetic vitamin A palmitate in corn oil, $^{2} 5$ of 16 apparently normal subjects failed to show any appreciable elevation of the serum vita-

1 This work was supported by grants from the WilliamsWaterman Fund and by Hoffmann-LaRoche, Inc. This paper was presented in part on October 31, 1953, at the 26th Annual Meeting of the Central Society for Clinical Research (in Chicago, Ill.).

2 Provided through the courtesy of Hoffmann-LaRoche, Inc. $\min$ A concentrations during the 8-hour period following the test dose. These subjects had, in addition to adequate dietary supplies of vitamin $A$ and normal fasting serum vitamin A levels, normal serum carotene values, which in our experience almost certainly exclude the presence of defective fat absorption. Accordingly, further studies were carried out to define the nature of this apparent absorptive defect. One of the subjects became hungry during the test, and was allowed to eat a sandwich and drink some coffee. A serum sample taken immediately after this meal revealed that his vitamin A concentration had increased from 45 to 350 micrograms per cent in 20 minutes. The results of the effects of eating upon the other four normal subjects who had failed to show any absorption of the test solution when fasting were the incentive for a more systematic study.

\section{METHODS}

1. Vitamin A was determined in small quantities of serum by the spectrophotometric method of Bessey, Lowry, Brock, and Lopez (5) utilizing the principle of destruction by exposure to ultraviolet light of the vitamin A present in a xylene-kerosene extract of serum. All samples were analyzed in triplicate for both carotene and vitamin $A$, in a Beckman model DU spectrophotometer, at wave lengths of 460 millimicrons for carotene and 328 millimicrons for vitamin A.

2. The test material consisted of clear solutions of synthetic vitamin A palmitate in corn oil, containing approximately 10,000 micrograms vitamin A per $\mathrm{ml}$. This was a very stable product, showing little or no deterioration in assayable vitamin $A$ when kept in amber bottles in the refrigerator. A single dose of $10.5 \mathrm{ml}$. of this oil was administered by mouth or through rubber tubes as described below.

\section{PROCEDURE}

1. Of the 16 normal healthy young adults selected as controls, eight were males. The five subjects who failed to show any absorption of the test dose when administered to them fasting were given a repeat dose one week following the first test, and exactly two hours later were permitted to eat whatever they wanted, completing the 


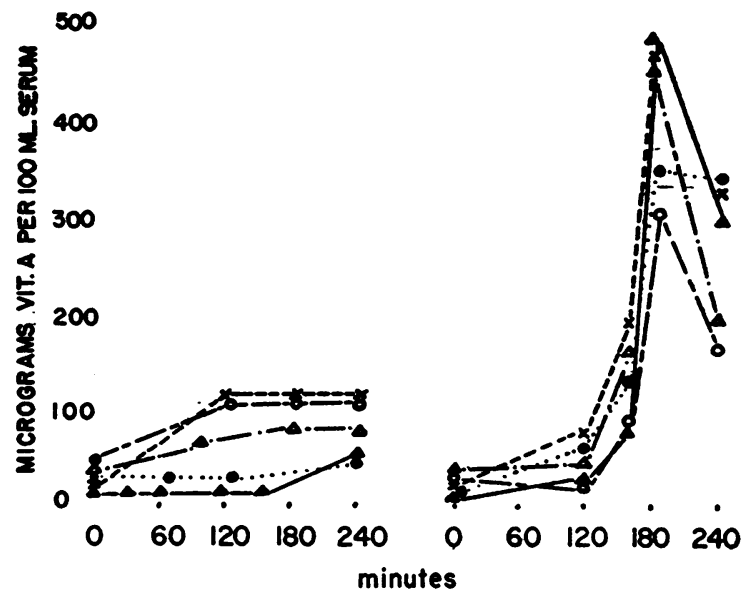

Fig. 1. Oral Vitamin A Tolerance Tests in Five Normal Subjects

On the left are results of administering test dose to fasting subjects; on the right the same subjects ate breakfast at 120 minutes following administration of the test dose.

meal within 30 minutes. Blood samples were taken before the test dose, at two hours (immediately prior to eating), at 150 minutes, at 180 minutes, and at $240 \mathrm{~min}-$ utes. The results may be seen in Figure 1 and Table I.

2. A second group of 16 normal control subjects and a group consisting of 32 hospitalized patients not clinically suspected of defective fat absorption were given the test dose, followed by their customary breakfast two hours later. Serum samples taken at $0,120,150,180$, and 240 minutes were analyzed for vitamin $A$ and the results plotted in Figure 2.

3. In six of the normal subjects from the first group, gastric tubes were passed under fluoroscopic control into the third portion of the duodenum. A mixture of 100,000 micrograms of vitamin A palmitate and $20 \mathrm{ml}$. warm water was gently emulsified and instilled through the tube:

TABLE I

Results of oral vitamin $A$ tolerance tests in normal subjects, using as a test dose 100,000 micrograms synthetic vitamin $A$ palmitate in corn oil

\begin{tabular}{|c|c|c|c|c|c|c|c|c|}
\hline \multirow{2}{*}{ Sub- } & \multirow{2}{*}{ Sex } & \multirow{2}{*}{$\begin{array}{l}\text { Carotene } \\
\text { mcs./100 } \\
\text { ml. serum }\end{array}$} & \multicolumn{6}{|c|}{ Vitamin A, micrograms/100 ml. serwm } \\
\hline & & & $\begin{array}{c}\text { Fast- } \\
\text { ing }\end{array}$ & $\begin{array}{c}120 \\
\text { min. }\end{array}$ & & $\underset{\text { min. }}{150}$ & $\begin{array}{c}180 \\
\min .\end{array}$ & $\begin{array}{c}240 \\
\min .\end{array}$ \\
\hline 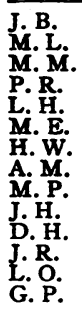 & $\begin{array}{l}\mathbf{M} \\
\mathbf{F} \\
\mathbf{M} \\
\mathbf{M} \\
\mathbf{M} \\
\mathbf{F} \\
\mathbf{M} \\
\mathbf{M} \\
\mathbf{F} \\
\mathbf{M} \\
\mathbf{F} \\
\mathbf{F} \\
\mathbf{F} \\
\mathbf{M}\end{array}$ & $\begin{array}{l}132 \\
199 \\
168 \\
132 \\
151 \\
115 \\
154 \\
138 \\
125 \\
157 \\
220 \\
116 \\
125 \\
136\end{array}$ & $\begin{array}{l}26 \\
46 \\
38 \\
58 \\
44 \\
44 \\
32 \\
46 \\
52 \\
46 \\
45 \\
29 \\
48 \\
50\end{array}$ & $\begin{array}{r}56 \\
98 \\
38 \\
200 \\
127 \\
65 \\
48 \\
97 \\
56 \\
216 \\
410 \\
218 \\
139 \\
62\end{array}$ & 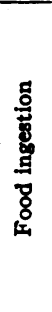 & $\begin{array}{l}118 \\
162 \\
280 \\
228 \\
141 \\
211 \\
117 \\
135 \\
109 \\
248 \\
532 \\
290 \\
505 \\
332\end{array}$ & $\begin{array}{l}\mathbf{3 8 0} \\
388 \\
\mathbf{3 6 2} \\
300 \\
270 \\
630 \\
\mathbf{4 8 8} \\
\mathbf{2 8 8} \\
\mathbf{3 4 8} \\
490 \\
192 \\
554 \\
748 \\
\mathbf{5 6 4}\end{array}$ & $\begin{array}{l}437 \\
401 \\
450 \\
327 \\
313 \\
705 \\
400 \\
210 \\
246 \\
248 \\
134 \\
432 \\
485 \\
542\end{array}$ \\
\hline \multicolumn{2}{|c|}{ Mean values } & 146 & 43 & 126 & & 241 & 442 & 402 \\
\hline \multicolumn{2}{|c|}{ S.E. mean } & \pm 7.5 & \pm 2.1 & \pm 25.0 & & \pm 32.5 & \pm 39.2 & \pm 35.1 \\
\hline
\end{tabular}

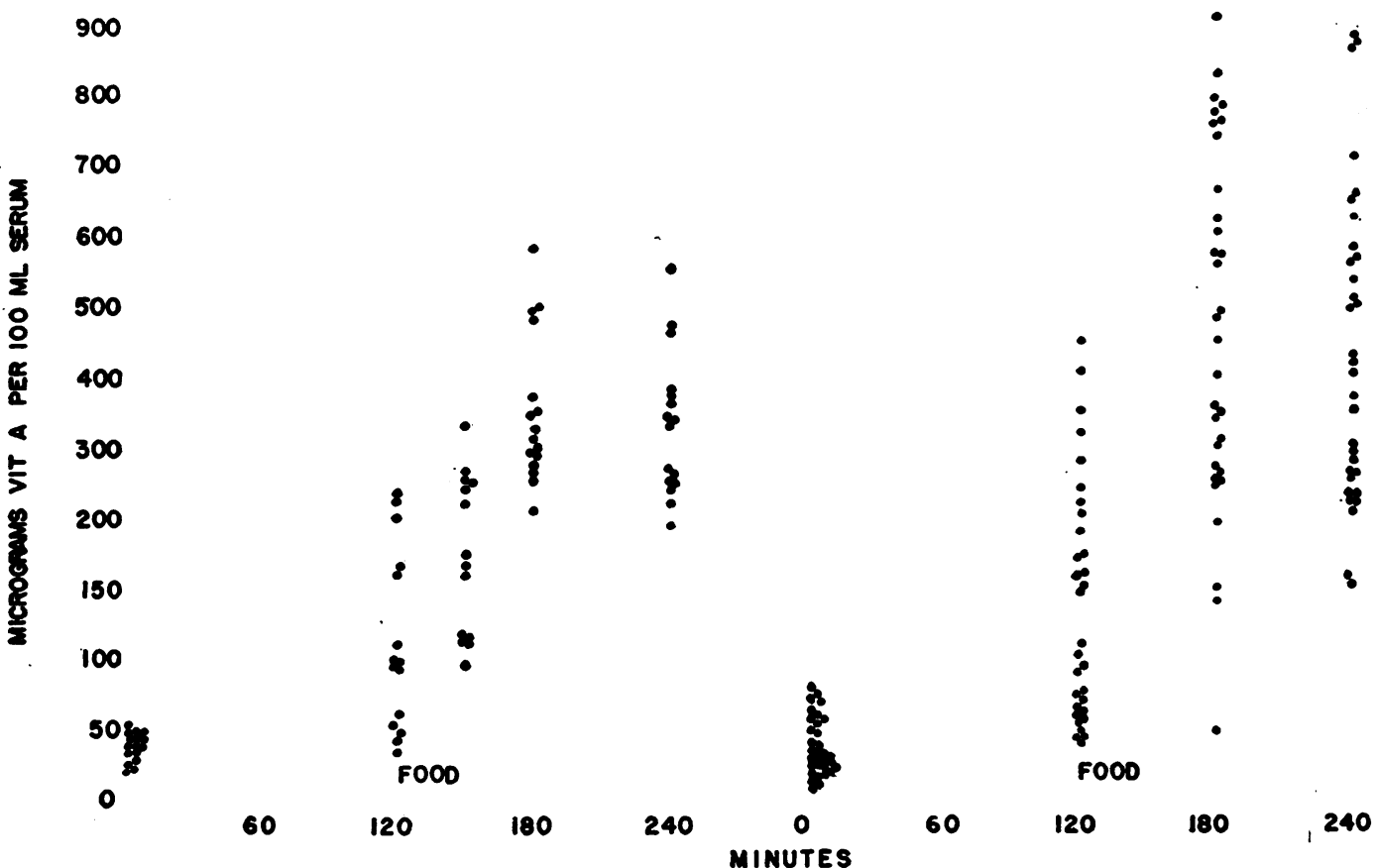

Fig. 2. Oral Vitamin a Tolerance Curves in Ambulatory Control Subjects (Left), and in Hospttalized Control Subjects (Right)

In both groups a normal breakfast was eaten at 120 minutes following administration of test dose. 


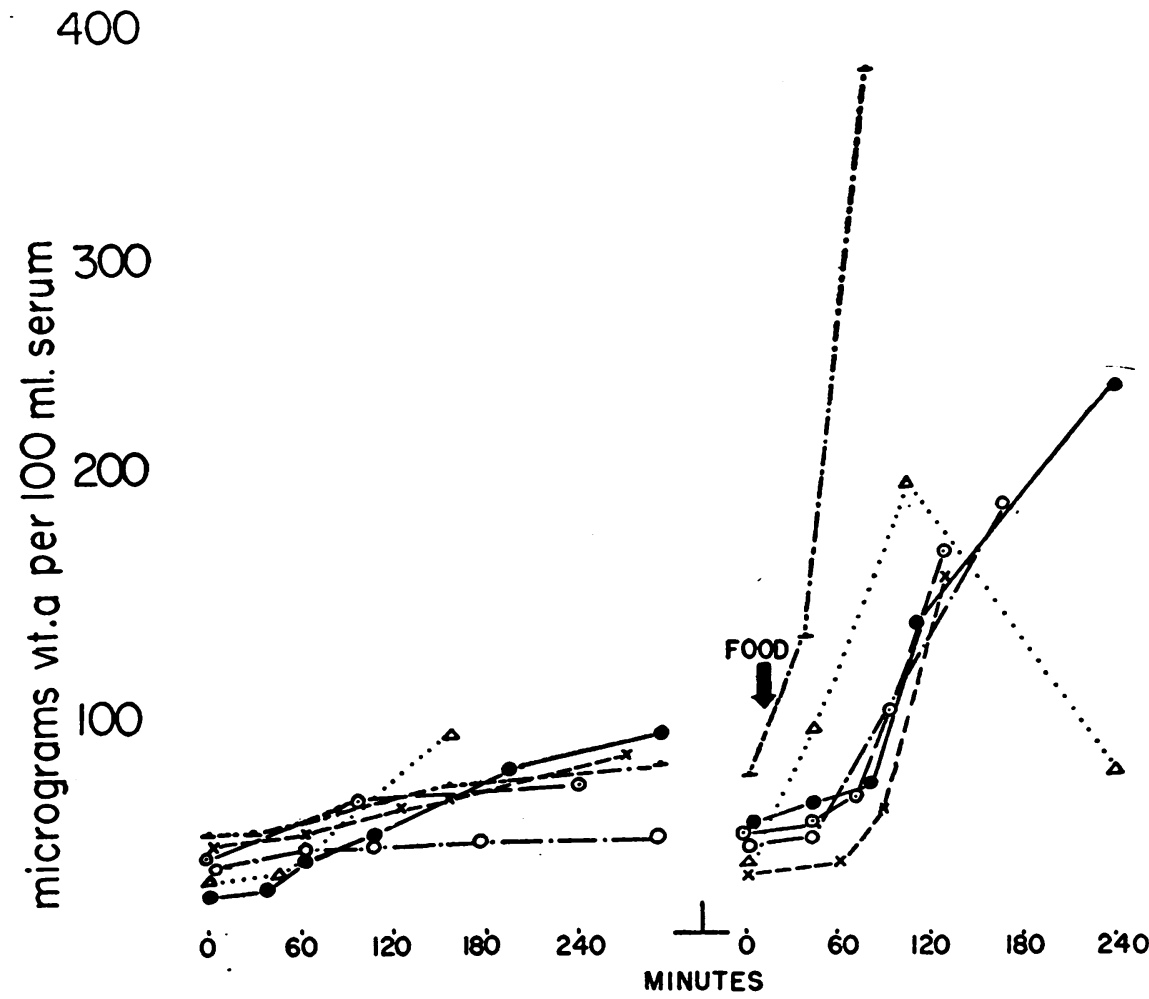

Fig. 3. Intraduodenal Administration of Vitamin A in Six Normal Subjects

On the left are results when subjects did not eat following instillation of test dose; on the right are results when subjects ate breakfast within $\mathbf{3 0}$ minutes following instillation of test dose.

the tube was then withdrawn and serum samples taken over the succeeding four hours. This same group of normal subjects was then given the same test one week later, but this time the subjects were allowed to eat breakfast immediately following instillation of the test dose. There was a significant increase in the vitamin $A$ absorption after eating, as may be seen in Figure 3.

4. In order to study the effects of an anticholinergic agent, four of these subjects then took the test dose orally, but 100 minutes later received an intramuscular injection of $1.0 \mathrm{mg}$. atropine sulfate. They ate breakfast twenty minutes following this injection, and had the usual blood samples taken. Two such tests were carried out in each subject. The results of this study are summarized in Table II.

5. In order to test the time relationships involved in the taking of food, two subjects with the intraduodenal tube in place ate breakfast, then had the test dose instilled 20 minutes later, after which the tube was withdrawn. The same two subjects one week later took the test dose first, followed within twenty minutes by the breakfast. To assess the effect of the presence of the tube itself, one of the subjects kept the tube down while eating his meal, and let it remain there during the next two hours. All five tests gave essentially the same results.

6. The same test was given to three subjects who had been totally gastrectomized within the preceding six months. One subject had an esophagoduodenostomy, two had esophago-jejunostomies; the results of all three tests were similar, and are recorded in Figure 4.

7. Sham feeding at two hours following the ingestion of the test dose was next tried; the five subjects thoroughly masticated an attractive meal, but expectorated all of it without swallowing so much as a drop of saliva; two hours later they ate, and retained, a similar meal. The results of all five tests are summarized in Table III.

8. An attempt to exclude biliary and pancreatic juice from contact with the test solution was made by "isolating" the proximal jejunum of two normal subjects between two recording balloons; the test solution of vitamin A was then instilled into this segment. In the study shown in Figure 5A, no absorption from the isolated segment could be detected, despite violent increases in amplitude of contractions and in tonus, as recorded by the two balloons; in the second part of this study, after a meal was taken, the distal balloon was deflated, allowing the vitamin A solution in the isolated loop to escape along the adjacent jejunum, and some absorption was noted Consequently, the distal balloon was deflated when the second subject (Figure 5B) was studied, in both the fasting and the fed states. 
TABLE II

Studies in normal subjects; one mg. atropine sulfate administered i.m. 100 minutes after ingestion of test dose of vitamin $A$ palmitate

\begin{tabular}{|c|c|c|c|c|c|c|c|c|}
\hline \multirow{3}{*}{\multicolumn{2}{|c|}{ Subject }} & \multicolumn{7}{|c|}{$\begin{array}{l}\text { Serum vitamin A concentrations, } \\
\text { micrograms per } 100 \mathrm{ml} .\end{array}$} \\
\hline & & \multicolumn{7}{|c|}{ Minutes after administration of test dose } \\
\hline & & $\mathbf{0}$ & 100 & 120 & & 150 & 180 & 240 \\
\hline M. M. & $\begin{array}{l}\text { control } \\
\text { atr. No. } 1 \\
\text { atr. No. } 2\end{array}$ & $\begin{array}{l}36 \\
40 \\
32\end{array}$ & $\begin{array}{l}\text { atrop. } \\
\text { atrop. }\end{array}$ & $\begin{array}{r}120 \\
102 \\
36\end{array}$ & \multirow{4}{*}{ 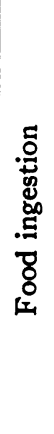 } & $\begin{array}{r}262 \\
136 \\
58\end{array}$ & \begin{tabular}{|l|}
486 \\
156 \\
122
\end{tabular} & $\begin{array}{l}484 \\
170 \\
430\end{array}$ \\
\hline M. L. & $\begin{array}{l}\text { control } \\
\text { atr. No. } 1 \\
\text { atr. No. } 2\end{array}$ & $\begin{array}{l}38 \\
40 \\
34\end{array}$ & $\begin{array}{l}\text { atrop. } \\
\text { atrop. }\end{array}$ & $\begin{array}{r}160 \\
118 \\
36\end{array}$ & & $\begin{array}{r}222 \\
130 \\
44 \\
\end{array}$ & $\begin{array}{r}286 \\
236 \\
52 \\
\end{array}$ & $\begin{array}{l}400 \\
220 \\
182 \\
\end{array}$ \\
\hline P. R. & $\begin{array}{l}\text { control } \\
\text { atr. No. } 1 \\
\text { atr. No. } 2\end{array}$ & $\begin{array}{l}44 \\
40 \\
48\end{array}$ & $\begin{array}{l}\text { atrop. } \\
\text { atrop. }\end{array}$ & $\begin{array}{l}98 \\
96 \\
50\end{array}$ & & $\begin{array}{r}162 \\
134 \\
62\end{array}$ & $\begin{array}{l}212 \\
230 \\
106\end{array}$ & $\begin{array}{l}220 \\
366 \\
220\end{array}$ \\
\hline H. W. & $\begin{array}{l}\text { control } \\
\text { atr. No. } 1 \\
\text { atr. No. } 2\end{array}$ & $\begin{array}{l}38 \\
36 \\
40\end{array}$ & $\begin{array}{l}\text { atrop. } \\
\text { atrop. }\end{array}$ & $\begin{array}{l}42 \\
60 \\
64\end{array}$ & & $\begin{array}{r}90 \\
128 \\
206\end{array}$ & $\begin{array}{l}250 \\
140 \\
228\end{array}$ & $\begin{array}{l}342 \\
360 \\
675\end{array}$ \\
\hline
\end{tabular}

\section{RESULTS}

In Figure 1 are clearly seen the rapid rises in serum vitamin A concentration immediately following the taking of a meal, in five normal subjects who had failed to show any absorption when
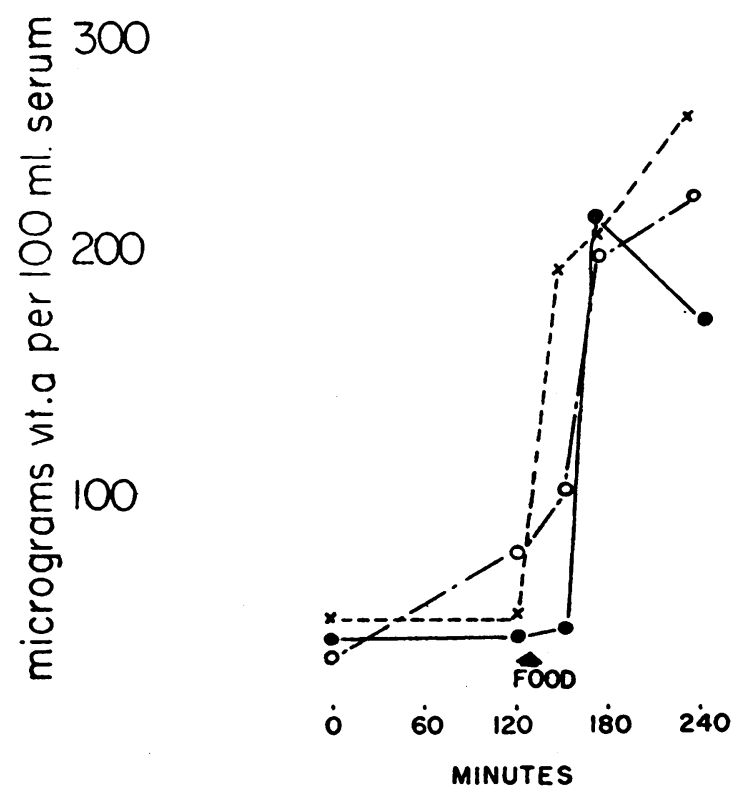

Fig. 4. Oral Vitayin a Tolmance Curves in Three Totally-Gastrectomized Subjects

A normal meal was given 120 minutes after ingestion of the test dose. fasting. The extension of this test to a larger number of controls, as seen in Figure 2, seems to confirm the remarkable stimulatory action of the taking of food upon the level of vitamin $A$ in the serum, although in many subjects the levels were already rising fairly rapidly prior (i.e., in the serum sample taken at 120 minutes) to the taking of food. In no one of these 48 tests did the serum vitamin A concentration fail to reach either a level greater than four times the fasting concentration, or an absolute value of 100 micrograms per cent during the four hours of the test.

The intubation studies depicted in Figure 3, and those described under "Procedure," paragraph 5, show that the effect of food was manifest whether the test solutions were instilled prior to eating or following the meal. That the presence of the stomach, and presumably of its acid-peptic secretions, is not requisite for this effect of food is provided by the studies on totally-gastrectomized subjects (Figure 4). More surprising are the results with sham feeding, which seems to possess stimulatory powers nearly equal to those of actual food ingestion, although the effect is not so prolonged (Table IV). The studies reported in Figure 5 were designed to prevent biliary and pancreatic juice from coming into contact with the test solution, although of course succus entericus could not be so eliminated. The administration of atropine 20 minutes prior to food ingestion had a statistically significant effect in delaying by 30 minutes the onset of the rapid rise in serum vitamin $A$ concentration usually observed after food ingestion (Table IV). The maximum serum concentrations attained were, however, not markedly different in the control and atropinized subjects.

TABLE III

Studies with sham feeding Serum vitamin A concentration, micrograms per $100 \mathrm{ml}$., obtained in normal subjects

\begin{tabular}{|c|c|c|c|c|c|c|c|c|c|}
\hline \multirow{2}{*}{$\begin{array}{l}\text { Sub- } \\
\text { jects }\end{array}$} & \multicolumn{9}{|c|}{ Minutes after administration of test dose } \\
\hline & 0 & 120 & & 150 & 180 & 240 & & 300 & 360 \\
\hline $\begin{array}{l}\text { D. C. } \\
\text { S. D. } \\
\text { I. P. } \\
\text { J. R. }\end{array}$ & $\begin{array}{r}38 \\
38 \\
37 \\
52 \\
60\end{array}$ & $\begin{array}{l}64 \\
68 \\
83 \\
96 \\
80\end{array}$ & 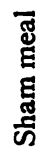 & $\begin{array}{r}84 \\
155 \\
260 \\
184 \\
206\end{array}$ & $\begin{array}{l}128 \\
235 \\
275 \\
228\end{array}$ & $\begin{array}{l}225 \\
285 \\
350 \\
280 \\
256\end{array}$ & 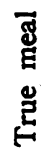 & $\begin{array}{l}- \\
\overline{400} \\
675 \\
390\end{array}$ & $\begin{array}{l}255 \\
370 \\
480 \\
\frac{620}{620}\end{array}$ \\
\hline
\end{tabular}




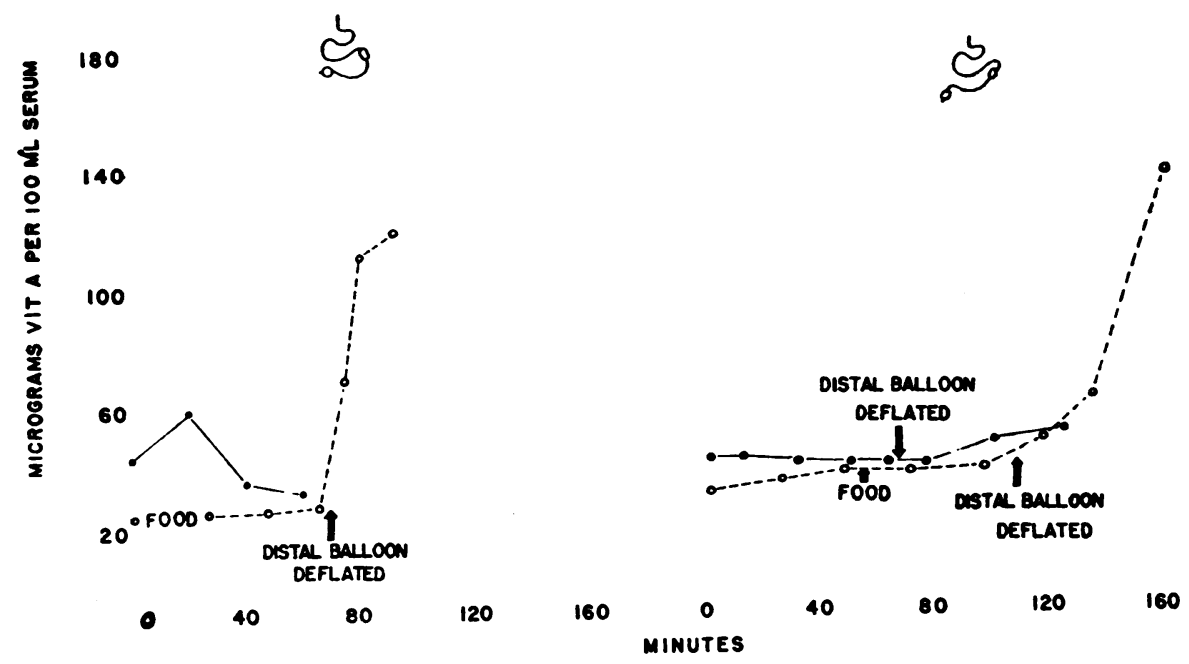

Fig. 5. A. (Left) Studies with Triple-Lumen Tube "Isolating" Jejunum of a Normal Subject

Test solution of vitamin $A$ instilled at $\mathbf{0}$ minutes; closed circles represent values in fasting subject, open circles in fed subject.

\section{B. (Right) Studies with Triple-Lumen Tube "Isolating" Jejunum of a Second Normal Subject}

Test solution of vitamin $A$ instilled at 0 minutes; distal balloon deflated in each studyfasting (closed circles), and fed (open circles).

\section{DISCUSSION}

These studies are concerned with the absorption of synthetic vitamin A palmitate, a more homogeneous substance than the usual preparations of natural vitamin A esters, which contain large amounts of vitamin $A$ acetate and variable quantities of vitamin A alcohol, both of which may be absorbed more rapidly than, or by mechanisms other than those involved in absorption of long-chain fatty acid esters. In general, the serum vitamin A levels in control subjects reported here rise less rapidly and reach lower concentrations than those re- ported for studies in which the natural esters have been the test solution (2-4). It would be distinctly unusual to find 5 of 16 normal subjects exhibiting "flat" tolerance tests after a test dose of natural vitamin A esters.

It seems clear from the experiments reported above that the act or thought of eating activates the mechanisms by which vitamin $A$ enters the blood stream, so that the rate at which the vitamin A concentration rises may be markedly increased within a few minutes. The experiments seem definitely to exclude gastric emptying or secretion as necessary for this activation; the possible role of

TABLE IV

Mean rates at which serum vitamin $A$ concentrations rise following the test dose, expressed as micrograms vitamin $A$ per $100 \mathrm{ml}$. per minute

\begin{tabular}{|c|c|c|c|c|}
\hline Type of study & No. of tests & $\begin{array}{l}\text { Period A } \\
\text { Fasting 0-120 minutes } \\
\text { (Mean } \pm \text { S. E. mean) }\end{array}$ & $\begin{array}{c}\text { Period B } \\
120-150 \text { minutes } \\
(\text { Mean } \pm \text { S. E. mean })\end{array}$ & $\begin{array}{c}\text { Period C } \\
\text { 150-180 minutes } \\
\text { (Mean } \pm \text { S. E. mean })\end{array}$ \\
\hline $\begin{array}{l}\text { Control } \\
\text { (Table I) }\end{array}$ & 14 & $\begin{array}{c}\text { Fasting } \\
0.73 \pm 0.23\end{array}$ & $\begin{array}{c}\text { During food ingestion } \\
4.1 \pm 0.92\end{array}$ & $\begin{array}{l}\text { After food ingestion } \\
7.3 \pm 0.91\end{array}$ \\
\hline $\begin{array}{c}\text { Sham Feeding } \\
\text { (Table III) }\end{array}$ & 5 & $\begin{array}{c}\text { Fasting } \\
0.32 \pm 0.11\end{array}$ & $\begin{array}{c}\text { During sham feeding } \\
3.34 \pm 0.76\end{array}$ & $\begin{array}{c}\text { After sham feeding } \\
1.98 \pm 0.46\end{array}$ \\
\hline $\begin{array}{l}\text { Atropine } \\
\text { (Table II) }\end{array}$ & 8 & $\begin{array}{c}\text { Fasting } \\
0.35 \pm 0.19\end{array}$ & $\begin{array}{c}\text { During food ingestion } \\
1.43 \pm 0.42\end{array}$ & $\begin{array}{c}\text { After food ingestion } \\
1.66 \pm 0.46\end{array}$ \\
\hline
\end{tabular}


the hormone villikinin in causing the intestinal villi to pump fat into the lacteals seems excluded here by the studies in gastrectomized subjects, since this hormone is postulated to arise from the contact of hydrochloric acid with the duodenal mucosa (6). The effects of sham feeding are reasonably clearcut; that eating and sham feeding increase the output of biliary, pancreatic, and enteric digestive juices is quite undeniable (7), but the studies with the "isolated" jejunum done here suggest that although intraluminal factors must govern the absorption of vitamin A from the intestine, they do not necessarily account for this sudden rapid entry of vitamin A into the blood stream.

The dose of atropine given in these studies produced a definite delay in the onset of the rise in serum vitamin A levels, the serum levels for the period immediately following eating being statistically lower $(P<0.05)$ than in control studies, but all four atropinized subjects did exhibit maximal concentrations in the serum within 240 minutes after taking the test dose which were comparable to those in the control studies. Such an effect resembles closely that reported by Ingelfinger, Moss, and Helm (8) in atropinized subjects fed natural vitamin A esters intraduodenally. Their studies seemed to implicate qualitative changes in digestive juices as influencing markedly the absorption of natural vitamin A esters from the intestine, but they were unable to delineate clearly the relative roles of digestive juices, intestinal motility, and other unknown factors in the absorption of vitamin A.

The rapidity of the rise in serum vitamin A which has been demonstrated in some of these cases directs attention to effects of the act or thought of eating other than those briefly discussed above. It has been known for centuries that the lacteals of animals may remain engorged with fat for hours after fed fat has disappeared from the intestine. A sudden contraction of these fat-filled lacteals would be capable of flooding the blood stream with vitamin A in a very short period of time. There are few data in the literature defining the factors which are capable of causing such sudden contractions, but it is well-established that the parenteral or oral administration of hypertonic saline has a marked stimulatory effect on lymph flow (9). Studies on the flow of thoracic duct lymph in experimental animals demonstrate marked variations in the speed and volume of this flow, but eating and drinking are usually followed by appreciable increases in both modalities (10, 11). Further studies along these lines are certainly indicated. There are many reports in the literature which make use of vitamin A test solutions either incorporated into or given with meals $(3,12)$. Analyses of the serum vitamin A concentrations obtained with such test solutions show them to reach higher levels more rapidly than those reported in subjects given the same test solution when fasting. The specific accelerating effect of the food or of eating is thus difficult to analyze, as compared with the technique adopted in the studies reported here, since the maximal stimulus to absorption is provided at the very beginning of the test, but few or no falsely flat tolerance tests have been described when this procedure is followed.

The clinical usefulness of the vitamin A tolerance test as described above, in which a meal is fed 120 minutes following administration of the test dose, seems well established by the results in this laboratory. In 106 tests performed on hospitalized patients 13 have failed to show a serum vitamin A level greater than four times the fasting concentration, or failed to reach 100 micrograms per cent within the four hours required by this test. All 13 of these patients have shown significant steatorrhea (i.e., fecal fat representing more than 8 per cent of ingested fat) on the basis of four-day fat balance studies, and many have presented the clinical stigmata of defective fat absorption as well. It would appear that the inclusion of a meal as a stimulus is a simple and convenient way of avoiding the flat tolerance tests which may occur in normal subjects. If vitamin $\mathrm{A}$ has been absorbed, the act of eating should cause most of it to enter the blood stream; if it does not appear after such a stimulus, one is quite justified in assuming that it has not been absorbed.

\section{SUMMARY}

1. Normal fasting subjects may demonstrate no appreciable rise in serum vitamin A concentration during the 8-hour period following ingestion of the test dose of vitamin A palmitate in corn oil.

2. The feeding of a meal two hours after the ingestion of the test dose activates the mechanisms whereby recently absorbed vitamin A enters the blood stream. Studies done on normal and gas- 
trectomized subjects, with and without eating, cast doubt that this mechanism is intraluminal. It is suggested rather that the lacteals may be activated in some way by eating to expel their contained vitamin $\mathrm{A}$ into the blood stream.

3. Sham feeding is almost as effective as food ingestion in activating this mechanism. Atropine seems to delay the response, but not to prevent its occurrence.

4. Failure of 13 subjects of 106 tested to demonstrate appreciable rises in serum vitamin A levels when fed a meal two hours after ingestion of the test dose of vitamin A palmitate was in all cases shown to be associated with significant steatorrhea.

\section{ACKNOWLEDGMENT}

The author gratefully acknowledges the technical help of Mrs. Mary Koch and of Mrs. Loma Coday.

\section{REFERENCES}

1. Gray, E. LeB., Morgareidge, K., and Cawley, J. D., Intestinal absorption of vitamin $A$ in the normal rat. J. Nutrition, 1940, 20, 67.

2. Clausen, S. W., The absorption of vitamin $A$ and its storage in the tissues. The Harvey Lecture Series, 1943, XXXVIII, 199.

3. Adlersberg, D., and Sobotka, H., Fat and vitamin A absorption in sprue and jejunoileitis. Gastroenterology, 1943, 1, 357.
4. Ralli, E. P., Bauman, E., and Roberts, L. B., The plasma levels of vitamin $A$ after the ingestion of standard doses: Studies in normal subjects and patients with cirrhosis of the liver. J. Clin. Invest., 1941, 20, 709.

5. Bessey, O. A., Lowry, O. H., Brock, M. J., and Lopez, J. A., The determination of vitamin $A$ and carotene in small quantities of blood serum. J. Biol. Chem., 1946, 166, 177.

6. Grossman, M. I., Gastrointestinal hormones. Physiol. Rev., 1950, 30, 33.

7. Babkin, B. P., Secretory mechanisms of the digestive glands. Hoeber, N. Y., 1950, 2nd edition, p. $860 \mathrm{ff}$.

8. Ingelfinger, F. J., Moss, R. E., and Helm, J. D., Jr., The effect of atropine upon the absorption of vita$\min$ A. J. Clin. Invest., 1943, 22, 699.

9. Drinker, C. K., and Yoffey, J. M., Lymphatics, lymph, and lymphoid tissue. Their physiological and clinical significance. Cambridge, Harvard U. Press, 1941, Chapter IV., p. 112, Lymph flow and lymph pressure.

10. Borgström, B., and Laurell, C.-B., Studies on lymph and lymph-proteins during absorption of fat and saline by rats. Acta physiol. Scandinav., 1953, 29, 264.

11. Shrewsbury, M. M., Jr., and Reinhardt, W. O., Comparative metabolic effects of ingestion of water or 1 per cent sodium chloride solution in the rat with a thoracic duct lymph fistula. Am. J. Physiol., 1952, 168, 366.

12. Week, E. F., and Sevigne, F. J., Vitamin A utilization studies. III. The utilization of vitamin $\mathbf{A}$ alcohol, vitamin A acetate and vitamin A natural esters by humans. J. Nutrition, 1950, 40, 563. 